\title{
REFORMS AND CHANGES IN NEPAL: POLITICAL-SOCIOLOGICAL PERSPECTIVES ON STATE RESTRUCTURING PROCESS IN THE POST-DEMOCRATIC PERIOD
}

\author{
Prakash Upadhyay (Nepal)
}

\begin{abstract}
Transitions, by definition, bring changes and the 1951, 1979-80, 1990 and 2006 transitions in Nepal were changes towards democracy. But all transitions before 2006 did not herald major inclusive reforms. Pedestal on the perspectives of Political Sociology, this article argues that political actors, including parties, pressure groups and social movements, operate within a wider social contexts and issues. The socio-political formation of the modern Nepali state is extremely bucolic and power centric hence who rules is a vital concern in Nepal. Political actors inevitably rule, shape, and in turn are shaped by blistering issues faced by the society. Issues as State restructuring often becomes a blistering controversial issue when a country is going federal on the basis of desegregation. Nepali society is extremely diverse and complex hence steps forward in Nepal is possible only from macro perspective which could be a yardstick in developing the Nepali society. As Nepal is a state of many nationalities, hence in post republican State restructuring in Nepal, not xenophobia but positive protests, civil society and political parties /opposition and factual devotion will provide the common bond of harmony in variety. In the process, the affects of public opinion, civic society, ideologies and social tendencies outside of the formal institutions of political power remains decisive.
\end{abstract}

KEYWORDS: Oligarchy, civil society, rhetoric, transition, political marginalization

\section{INTRODUCTION}

Nepal is moving into a path of new nation building, known as 'New Nepal' after the establishment of Loktantra (Democratic Republic) from the success of Jana Aandolan II (Peoples' Movement II). The aftermath of Peoples' Democracy is not gratis of predicaments. The debacle of first constituent assembly in 2012 to embark the triumph of Peoples' Movement is an example. The instantaneous task in the nation building is to safeguard the achievements of Loktantra in the form of inclusive and participatory democracy. Currently this is being done through writing a new constitution by the second constituent assembly, which aims to permanently transform the country from semi-feudal partial democracy into an inclusive republican democracy. However, the vital contested issues are the extent of socio-political inclusion of diverse ethnic groups (ethnic/national, caste, religious, linguistic, and regional identity) and forms of democratic federal structures for the 'New' Nepal. These contested issues are vital because they will have an effect on a majority of Nepalese but the country failed shoddily to achieve these in the past. The majority of its diverse citizens were excluded from various realms of social and political action for most of 


\section{Crossing the Border: International Journal of Interdisciplinary Studies}

Nepal's two and half centuries of existence while attempts at democratization since the fifties failed multiple times.

The socio-political formation of the modern Nepali state is very illogically built. The long established subsistence agriculture based semi-feudal authoritarian governments, social, cultural and political hypocrisy and feudalistic nature of governance has given birth to a modern form of internal and external anomalies. The residual of feudalism with political and dependency nexus endure constantly in 21st century which is discernible in various politico-social malfunctions. High privileged culture and exclusivity dominates urban as well rural Nepal because of semi-feudal sadistic cycle. The term 'elite' itself is confusing and resilient in Nepal with various meanings and interpretations, depending upon the type of establishment, society, agro-based economy, culture and change. These interpretations and conditions are influencing and hindering social-political reforms and State restructuring in Nepal.

\section{OBJECTIVES}

The key objectives of this article are to explore key reforms and changes in Nepal and to discern major challenges and constraints in State Restructuring process. Embedded with the notions of Political Sociology, this article focuses on three key areas:

1. The socio-political formation of the modern Nepali state;

2. "Who rules"? Social inequality between rulers and groups (class, ethnicity, gender, etc.) and their role in influencing Nepali politics and society; and

3. Affects of public opinion, civic society, ideologies and social tendencies outside of the formal institutions of political power in affecting formal politics and society in Nepal.

\section{DATA, METHOD AND CONCEPTUAL FRAMEWORK}

This article is based on secondary data which were obtained from various literatures, books, journals, booklets, articles, websites etc. Within the Political Sociological theoretical sketch of state, society and citizens relations, this article is based on the perusal of inconsistencies in relations amidst a vicious cycle of political, economic and social crisis, and the quest for political and social changes explicable on the base of a set of hypotheses about social/cultural, ethnic, regional, economic and political relations--a demand for more autonomy, social/cultural/political inclusions, ethno-regional, economic, relations between political parties/opposition, civil society and protests, inclusiveness and more vibrant democratization process. The conceptual framework explains elaborately:

Figure 1: Outlook on Political Flux and Crises: Political Sociological Perspectives

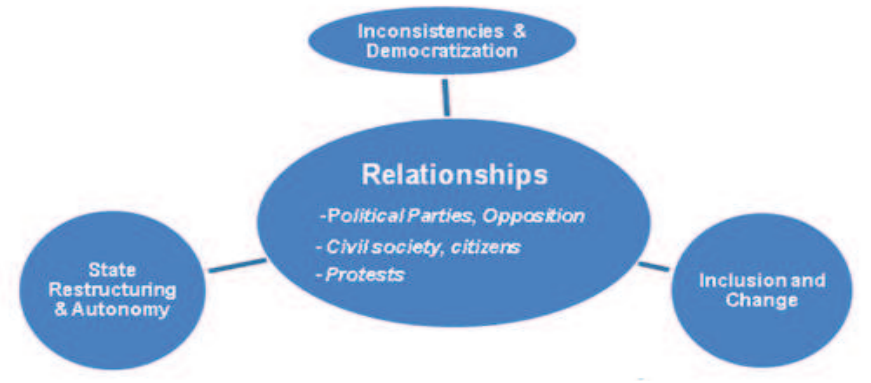




\section{REFORMS AND CHANGES IN NEPAL . . .}

Modern political sociology involves the study of the relations between state, society and citizens (Nash, 2010). Political sociologists ask: How is the body a site of power? (Sassatelli, 2011). Political sociology recognizes three key theoretical frameworks: pluralism, elite or managerial theory and class analysis which extend beyond Marxist analysis. Pluralism sees politics principally as a contest among competing interest groups. Elite or managerial theory shed light on what the state does by looking at constraints from organizational structure, semi-autonomous state managers, and interests that arise from the state as a unique, power concentrating organization. Social class theory analysis emphasizes the political power of capitalist elites (Coser, 1977). It can be divided into two parts. One is the power structure or instrumentalist approach, another is the structuralist approach. The power structure approach hub on 'who rules?' The structuralist approach accentuate on the way a capitalist economy operates; only allowing and encouraging the state to do some things but not others. In the Nepali context the vital concerns are the role of the state, play of power and politics across societies, which include, but are not restricted to, relations between the state and society.

For pluralists (Dahl, 1989) the distribution of political power is not determined by economic interests but by multiple social divisions and political agendas. The diverse political interests and beliefs of different factions work together through collective organizations to create a flexible and fair representation that in turn influences political parties which make the decisions. The distribution of power is then achieved through the interplay of contending interest groups. The government in this replica functions just as a mediating negotiator and is free from control by any economic power. This pluralistic democracy however necessitates the existence of a fundamental framework that would proffer mechanisms for citizenship and expression and the opportunity to organize representations through social and industrial organizations, such as trade unions. Eventually, decisions are reached through the complex process of bargaining and compromise between various groups pushing for their interests. The pluralist emphasis on fair representation that overshadows the constraints imposed on the extent of choice offered (Dahl, 1989). A truly pluralist society is consequently not attuned with the patterns of socioeconomic inequalities that prevail in a very asymmetrical country Nepal where social-economic disparities are very spiky. In Nepal, course of iniquitous political developments started with Rana autocratic oligarchy, authoritarian Panchayati system and come to multiparty system, parliamentary democracy then faced Maoist armed conflicts and then become the federal democratic republic of Nepal. Till present time, political change in Nepal was held within a time frame depicting the capricious nature of Nepali politics. This lacked the leadership vision for Nepal's future. Nepali mass movements and political parties brought the program with short term solution and gain the power. For sustainable solution, political parties programs were not implemented. All ruling elites and political parties gave priority to the programs which would assure them to attach in political power and in the process Hindu caste system and socio-cultural formation of the Nepali society have vital specific influences and it is affecting the structural formation of political organization and politics in Nepal. Same as caste system of Hindus such as hierarchical structure like top to bottom, hereditary basis of membership, the political hierarchy and hegemony is operating in diverse forms. In the process high caste 


\section{Crossing the Border: International Journal of Interdisciplinary Studies}

Hindu cultural features have influenced the political and social development in course of Nepal democratic movements.

The power structure approach 'who rules' is crucial. Throughout its history, there has been the existence of various types of ruling Hindu elites, political elites or elites of different kinds in the social and economic strata of Nepalese society that helped to generate disparities between people and people and dilute common Nepali's aggravation. Before the Rana regime (1768-1846 AD), few elite families ruled Nepal under the banner of Shah Kings. During Rana regime (1846-1950 AD), members of the autocratic feudalistic familial oligarchy of Rana family held absolute control of the government in Nepal. After the end of Rana oligarchy in 1951 first free elections were held in 1959 and a new constitution introduced. In 1960 all political parties were banned and the democratic constitution suspended. In 1962, a new constitution was drafted which set up a party-less Panchayati government and party-less council known as the Rashtriya Panchayat with king as the autocratic executive head of the elite government. Few elite families who were in proximity to Narayanhiti Royal Palace were dominant, took advantage and emerged as neo-elites. In the long run they became politically influential privileged and a sharp polarization between them and the common masses occurred. Intense concentration of elites in Kathmandu resulted in regional bias in development, the comparatively high development of Kathmandu and core urban areas and the underdevelopment and marginalization of secluded periphery regions and the people due to which Nepal remained gripped in a feudalistic socioeconomic structure and values in the mid-twentieth century despite the influence of Western popular culture, growing commercialization, and unrestrained penetration of capitalism. The first challenge to this feudalistic power structure came in 1990, when the autocratic party less Panchayati regime was toppled by popular democratic movement that restored multi party democracy and constitutional monarchy understood as a maturation of contradictions in a long process of social development and struggle in Nepal amid the sharp differentiation in economic matters. Democratic period remained embedded in uneasiness since the elections of 1991. Since 1991 to 2013, Nepal saw an assortment of forms of government (single to jumbo coalitions), political malfunctions, constituent assembly and its failure to draft a new constitution, social and economic anarchism and the political instability that jeopardized the country. This led to augment of frustration for politics and democracy in Nepal.

Democracy proved to be a corrupt practice in Nepal. Dahal (2000) argues that even in modern democratic age, poor people in Nepal are not the real beneficiaries in development projects and the elites living on the top have always remained the true beneficiaries of all development models. He further argued that Nepali culture in essence, is strictly built hierarchical and inherently built -in with the values of ambiguities and contradictions in everyday speech and work and because of these perpetuating cultural values, the Nepalese democracy has not been able to cross the barriers of caste, family and kinship and therefore leading towards 'inaction' and unrests in every aspect of the society. Even after all political exercises, the governance system remained the reflection of the past legacy; the old traditional elites still occupying key positions in every institution all over the country. The same domineering elitist structure based on family and kinship nepotism operates and 


\section{REFORMS AND CHANGES IN NEPAL . . .}

the bottom-up process of democratic politics remains a secluded dream in Nepal even in a republican set-up. Real Democracy remained part time -democracy only for few privileged. The grassroots democracy stands only rhetoric and an apparition for majority with differentiation in terms of differences in wealth and access to political power divided into different sub-sectors--small ruling elite; a growing, intermediate-sized group of government officials, large landholders, and merchants; and the vast majority of the population, consisting of a peasant base. These dissections are evocative, functional class categories rather than social class entities based on the Marxian concept of the social relations of production. In a way, all classes were a long continuum in Nepal's social structure because the majority of the members of the ruling elite and government functionaries had their direct roots in the rural landlord, which was one stratum of the farming population. Even though the agricultural sector as a whole faced similar economic and technological circumstances, it was diverse and contained several strata in landholding, relative economic dependence, and independence. Nepalese politics and economy took the form of distinguishing different political and capital fractions and of providing an account of the sufferings of commons and monopoly phase of political, economic and cultural privileged.

However, the advent of multiparty democracy of 1990 provided an opportunity for articulating the pains of historical injustice and long-standing legitimate grievances of indigenous peoples, women, Madhesis, Dalits and other marginalized communities in Nepal. The promulgation of new constitution of Nepal in 1991 states equality to all citizens of Nepal before law. Nepal was declared as multi-ethnic, multicultural and multi-lingual, democratic, independent, indivisible sovereign state. Thus, for the first time, the constitution of the kingdom of Nepal recognized Nepal as plural societies. In comparison to the constitution of Panchayat era, the constitution of 1990 looked more progressive. At least in principle, the new constitution guaranteed multiple parties, civic rights, freedom of speech, freedom of organization, freedom of languages and freedom of religious practices. For the first time in the political history of Nepal, Nepali people enjoyed political rights even in its limited form. Various indigenous groups, women, Madhesis and other disadvantaged communities became assertive in an organized form for their collective and ethnic identities. The multiparty democracy provided indigenous peoples, women, Madhesis and Dalits with an impetus to quest for equal participation in the national politics and policymaking processes. Nevertheless, the multiparty democratic system failed to address indigenous people, women' and other marginalized communities' hope to reduce socio-cultural and politico-economic inequalities and promote human rights. The declaration of Nepal as the Hindu kingdom in the multiparty democratic constitution of 1990 legally prohibited indigenous peoples and other religious minorities from practicing their religions in a practical manner. Similarly, the state's recognition of Nepali as the language of the nation and language of official business certainly discouraged the protection and promotion of various languages of indigenous peoples and other linguistic groups. The elimination of the practice of untouchability based on Hindu culture and gender inequality promoted by the patriarchic Hindu society became rhetoric of everyday politics rather than a reality. Situation became much shoddier even during post-democratic Nepal that laid the seed of political debacles and yet another uprising in the form of Maoist insurgency, provided opportunity to 


\section{Crossing the Border: International Journal of Interdisciplinary Studies}

monarch to grab power and ultimately the popular movement part-II in 2006 that concluded with the eradication of monarchy and establishment of federal democratic republic.

\section{RESTORATION OF DEMOCRACY AND ITS AFTERMATH}

The Nepali experience suggests that a democratic regime may be more responsive than an autocratic one, but it may only introduce minor reforms as seen from the democratic constitution of 1990. This supports the thesis that policy changes in democracies usually occur incrementally if there are no major crises (Truman,1951; Lindblom, 1959). After the establishment of multiparty democracy in 1990, major reforms were obstructed in Nepal because the state was overwhelmingly dominated by the dominant group and the democratic rule of the game was set up based on the majority principle where most of the state power was enjoyed by the party/group in power. This implies that democracy by itself may not lead to major inclusive reforms. The query then is what or which event or process caused the major inclusive been declared for indigenous nationalities, religious minorities etc. After the establishment of democratic republic, the Constituent Assembly (both I and II) has become the most representative legislature ever in Nepali history. Despite many shortcomings on the representational sector and with issues like ethnic autonomy and equal recognition of native languages not yet decided, on balance the 2006 political transition has brought the most inclusive reform in Nepal's history. Transitions, by definition, bring changes and the 1951, 1979-80, 1990 and 2006 transitions that were changes towards democracy. But all transitions before 2006 did not herald major inclusive reforms. Exclusion continued even during the 1990-2002 democratic years. The social movement literature argues that if people mobilize, such collective actions could pressure governments to introduce reforms (McAdam, McCarthy, and Zald, 1996; Tarrow, 1998). Transitions towards democracy (1951, 1979-80, 1990, and 2006) occurred due to popular mobilizations that demanded democratic reforms. Influences of public opinion, civic society, ideologies and social tendencies outside of the formal institutions of political power stood crucial in affecting formal politics and society in Nepal.

However, the social movements of the excluded groups in the nineties were not able to get major inclusive concessions. One explanation for the failure of the social justice movements is that the movements, despite exploding in the 1990s, were relatively new and they may not have developed enough organizational and mobilization strengths (Lawoti, 2005). Whatever the reasons, it is clear that the social justice movements of the excluded groups were not able to bring major inclusive changes, which were introduced only after the 2006 regime change.

Once the political change occurred in 2006, however, the Madhesi utilized the fluid opportunity to launch a successful movement in 2007 that forced the government to accept federalism. It also significantly contributed in making the government accept the mixed electoral method for the Constituent Assembly election. Madhesi movement became successful only after the 2006 regime change. Transition period could witness mobilization for changes because the old institutions are dismantled or discredited but new institutions are not set and the fluid situation generates incentives for change seeking agents to mobilize and push for changes as they rightly perceive that changes are more possible during transitions (Gurr, 


\section{REFORMS AND CHANGES IN NEPAL . . .}

2000). A combination of fluid situation due to the ongoing transition and particularly the Madhesi movement that became successful because of it at that particular juncture, contributed in heralding a few major inclusive reforms but other major reforms had already taken place. Social movements by themselves did not bring about the major inclusive changes in the country before the 2006 transition. The 2006 regime change and subsequent inclusive reforms points out a few things if analyzed from a historical perspective. First, regime change from autocracy can facilitate inclusive reforms but as demonstrated by the 1990 and earlier transitions, regime change is not enough to bring about inclusive reforms. Except for cooptation of a few minority individuals and minor reforms, substantial inclusive reforms did not occur during the earlier democratic transitions. The 2006 transition was different from all the earlier changes. The forces that were demanding or committed to inclusive reforms (the Maoists, ethnic organizations and ethnic parties) were a part of the coalition that forced the royal regime to buckle down in 2006 while powerful inclusion seeking forces were absent in earlier democratic transitions. The regime change was possible with the joint mobilization of the civil society (including ethnic organizations), parliamentary political parties (including ethnic parties), and the Maoists. The free media, which became more professional and which expanded in the nineties, also gave considerable coverage to the Maoists agendas, issues and activities (Mishra, 2004).

Even before the people's popular movement part-II new reforms became visible in 2003 when the government, in cooperation with civil society, draw up Nepal's first National Human Rights Action Plan (NHRAP). The first of its kind in the region, the Action Plan intended to give equal attention to civil, political, cultural, economic and social rights. The Ministry of Women, Children and Social Welfare has the role of coordinating gender mainstreaming efforts in Nepal. Key legislative measures aimed at the promotion of gender equality and the elimination of discrimination against women in Nepal includes: the five-year strategic plan of the National Women's Commission (2009-2014); the Domestic Violence (Crime and Punishment) Act, 2009; the Human Trafficking and Transportation (Control) Act, 2007; the National Women's Commission Act, 2007; and the Gender Equality Act, 2006. The National Women Commission (NWC) was established by the Government of Nepal through an executive decision in 2002 and a separate Act was promulgated in 2007. It has a legal mandate to monitor and investigate cases of violence against women, providing legal aid, monitor the state obligations, coordinate with government and other agencies for mainstreaming gender policy in national development and recommending and monitoring for the reforms by making research.

The regime transition of 2006 brought major political transformations, and unlike the previous transitions has made some significant impact on exclusion/inclusion as well. The state was declared secular in 2006 while the Hindu monarchy was abolished in 2008. Citizenship certificates were distributed in 2007 to more than two million Nepalese who were denied them earlier, mostly Madhesi but others as well. Irrational distribution of citizenship certificates, however, created serious controversies. It was alleged that many Indian nationals had got Nepali citizenship certificates. The Madhesi movement of 2007 also forced the ruling coalition partners to amend the Interim Constitution to declare that the country would adopt a federal structure in place of the unitary system. The reservation policy begun in 


\section{Crossing the Border: International Journal of Interdisciplinary Studies}

2003 by the royal regime was expanded after 2006 to include the Madhesi as well. The election to the Constituent Assembly in 2008 was conducted with a mixed proportional electoral method that helped to elect many members of the marginalized communities.

After the regime change, perspective has broadened to look into ethno nationalism. There were several types of movements and people began to raise their voices to empower their communities. Particularly the Madhesi and ethnic-based nationalism and declaration of autonomous states in Naya (New) Nepal created a new space in Nepali politics. Principally political parties are giving political framework to nationalism issue in the various ways such as ethnics; linguistic, regional issues were rose during mass movements. Madhesi movement is one of nationalisms and it does not include the all Nepali people who live in hill or even in Tarai. Madhesi movement was a landmark event in bringing out regional based ethnonationalism as one of the prominent issues in the national discourse on restructuring the Nepali state. Before that, public debate on ethno-nationalism was Janajaticentric (ethnic group centric) and social scientists belonging to Janajati. After the first Constituent Assembly election, Nepali politics and society divided in many factors in the name of state restructure and nationalism within their own nationals. It is not only a dive in the Nepali people but also a sever situation where many people were displaced due to so called Madhesi upraising in the southern lowland region of Nepal in 2007.

Nepali peoples' identities and unity became in risk due to nationalism issues spread in Madhesh and some hilly region especially in eastern region of Limbuwan. In the meantime, foreign NGOs and INGOs backed the ethnic communities to identities issues which made Nepali politics and society more unstable. Many new kinds of problems appeared in the frontline political discourse and fragmented society in some extent and threatened the internal sovereignty and harmony of nation. However, Nepal's post conflict situation lacks the management process such as implementation of understanding between parties, and agreements reached during the Comprehensive Peace Agreements. In addition, there is a lack of ensuring transitional justice and the rule of law functioning mechanism. There is a gap in the facilitation of disarming, demobilizing and reintegration and restructuring of security sector. The gap between the general public and political parties are widening. There is the lack of a civic culture on the part of Nepali political leadership, needed for building an advanced system to govern the people. This brings a gap among the people and different communities. In democracy building of post-conflict society like Nepal passion, tolerance, social learning, reconciliation and change in attitude are very vital considerations.

Timely and periodic change provides institutional resources to new groups for social mobility and political participation and makes conflict unnecessary. De-politicization of citizens leads to subject political culture while active political engagement of citizens promotes civic culture. This implies the citizen should take a number of initiatives and actions to determine policy and political decisions. Democratic process, insurgency and rebellions, regime change, and social movements could facilitate reforms. The vial question is which political process or events facilitated them in 2006 (and not during earlier transitions)? The opening up of the polity could lead to further reforms. Introduction of mass electoral politics empowers voters, and 


\section{REFORMS AND CHANGES IN NEPAL . . .}

citizens could vote for their choice, forcing democratic leaders to respond if they want to perform well in future elections (Dahl 1971). The demands and pressure upon the democratic political actors would force the state to respond and introduce reforms. However, this did not happen in Nepal with regard to inclusive reforms during the past democratic epochs. Major reforms to address demands for federalism and regionalism, ethnic groups, religious minorities, the proportional electoral system, a secular state, the multiple language policy, reservations in public offices and admission to education institutions, citizenship certificates to those without them, and an end to substantial cultural and caste discriminations were not initiated during the 1990-2002 democratic years. Yet, the issues of economic equalities remained untouched in the post democratic republic period.

\section{STATE-RESTRUCTURING PROCESS: CHALLENGES AND CONSTRAINTS}

Nepali peoples have not yet been able to experience the changes in their day to day life as per their expectations. The government has not implemented its commitments to address issues raised by indigenous peoples, women, Madhesi, Dalits and other marginalized groups during their movements. The democratic government's policies and programs look highly ambitious, but the new policies and programs have failed to satisfy the needs and aspirations of indigenous peoples, women, Madhesis, Dalits and other marginalized communities. This certainly has raised aggravation among these groups. The major political parties agreed to endorse all the earlier consensus and works made by first constituent assembly. But, the new constitution making process ensuring the social, cultural, economic and political rights of indigenous peoples, women, Madhesis, Dalits and other marginalized communities is very challenging issue. The restructure of the state along the line of federalism on the bases of ethnicity, languages and geographical territory is another challenging issue. Indigenous peoples, women, Madhesis, Dalits and other marginalized communities have their own specific problems of identity, representation, participation, and social inclusion in every sector of their social life. They demand human rights-based development programs such as food security, education, health, decent works and income generating activities at the community level. The government face a critical time because it has many challenges to counter in the days to come. The fulfillment of basic needs of peoples, maintenance of law and order, rehabilitation of displaced peoples and families and reconstruction of destroyed development infrastructure are among many other serious problems to be solved by the new government. Under such circumstances, the issues of indigenous peoples, women, Madhesis, Dalits and other marginalized communities may be overlooked. In such a case, Nepal may face a serious social and political crisis or any new type of insurgency in the near future.

The caste ridden and priest ridden Nepali society depicts a highly asymmetrical society in which caste, ethnic, religion and political factors plays a vital role in determining the status of an individual and a group. The unequal allocation of natural resources including farming land in an agricultural country like Nepal demonstrates how undemocratic Nepal is in a real sense. This has given rise to social tensions, prejudiced development and discriminating paucity. Nepal's prototype of land ownership (a reminiscence of feudalism) is the consequence of over two and half centuries of autocratic monarchy and Rana regime, with successive Shah 


\section{Crossing the Border: International Journal of Interdisciplinary Studies}

kings and oligarchic Rana rulers treating the land as their private property; allocating large tracts to the people close to them especially the government officials, priests, military leaders, and family members, in lieu of salaries or as gifts for their devotions. This feudal system deliberately excluded common people from owning land (a symbol of power and prosperity) and ensured their continued position as excluded agricultural tenants. Dominant groups close to the ruling elites held large tracts of land and were influential, but those who were never close to ruling elites such as Dalits and many other ethnic groups became the excluded groups in the long run and they became dependent on the former forever. However, some other groups who tended to lose land due to debts or any other socio-economic or political reasons (official confiscation of land) had not sufficient to continue to subsist. Mainly the ethnic groups, Dalits and other groups had to depart and look for occupation and land in India and Bhutan. This process continued for centuries but halted in 1990 when there occur political changes with the restoration of multiparty democracy after a lapse of thirty years. The emerging trend of globalization in early nineties amid rising unemployment and political instability inspired many young people (from all caste and ethnicities) to seek jobs in gulf countries and south-east Asian countries instead of looking for occupations in India and other neighboring countries where their ancestors had been going for the past many centuries for making a living.

In the case of Terai, before the emergence of the modern concept of nationhood and citizenship, Shah rulers, in the mid-eighteenth century, in the name of nationalism, had given high political and social-cultural priority to hill dwellers. For the Shah and Rana rulers, Terai was a mere satellite, a colony to extract revenue from land and natural resources. The Nepali nationalism, largely conceived and institutionalized, structured around the Hindu monarchy, Rana oligarchs, autocracy, Hindu religion and the Nepali language. These restrictive concepts always excluded Terai people, whose distinct cultures and cross-border link with India have led hill Nepalese to view them with suspicion and disdain. The psychological distance between Terai people and the Nepali state, as well as other citizens, has been historically motivated by discriminatory policies. Some of this distance is centuries old but much reflects the more deliberate constructs of Rana oligarchs and party-less Panchayati policies. The Panchayati slogan "one country, one dress, one language" proved perilous to Terai people and to many ethnic groups. The slogan one dress, one language tried to design a new united Nepali identity with a common dress Nepali trouser and Nepali cap and one language (Nepali language) excluding all others, but failed despicably to give equal caste/ethnic/religion/region based egalitarianism to all Nepali masses. The cumulative effect as a form of internal colonization of Terai proved precarious and demand liberation from domination. Owing to a justifiable grievance of the people of the Terai, because of political marginalization, failure to recognize their numbers and so on Madhes is a lumpy category although other groups like the Tharus disassociated themselves from Madhesis. Gaize (1975) had rightly predicted that though Madhesi discontent may be latent and dormant at present however may be grave and explosive in future. Gaize's prophecy came true in 2007 when the Terai movement erupted 32 years after the publication of Gaize's book. The low level of human development associated with pronounced spatial disparity and social exclusions - social, cultural, political, religious, educa- 
tional, etc. is entirely a cultural and political construct, stereotyped by the attitudes of influential power mongers.

The post-democratic period of 1990 proved to be capricious from all aspects. For the first time in its history, the issue of ethnicity-building was raised. New ethnic identities were forged, new associations set up, and new allegations made in social, political and economic sectors. The kind of national identity that was propagated in schools and through government organizations with autocratic legacy of the past was noticeable as highly exclusionary by ethnic groups, lower castes, by religious minorities, and by ethnic Madhesis living in the economically decisive Tarai region. Madhesis alleged that the hill dwellers of Nepal have developed an ethnic stereotype towards the Madhesis which is a simplified and often misleading representation of an ethnic group, composed of what are thought to be typical characteristics of members of a given group. Other ethnic groups also assert that throughout their history they have been excluded from various rights, hence, they bicker; the issue of their exclusion should be linked with the issue of ethnicity. In the past, ethnicity and religion never became a prominent issue in the politics of Nepal. This was particularly the case during the party-less Panchayati era, during which a sturdy emphasis was put on the undesirability of religious and ethnic politics as part of the efforts to consolidate national identity and unity. After the people's revolution in 2006 and the consequent establishment of republican set-up in 2008, both forms of identity seemed to come increasingly to the forefront, and accusations of ethnic or religious bias as well as exclusion are today commonly voiced in the political discourse of the country. Although this logic seems lucrative politically, but there are dangers of defining exclusion only in terms of caste and ethnicity.

Social exclusion is primarily concerned with the relationship between the individual and society, and the dynamics of that relationship. In fact, in many ways, it appears useful to emphasize similarities between the debates about social exclusion and the debates as no societies and groups in the world are entirely inclusive, yet the groups affected and the degree of discrimination varies from one society to another, as do the forms that social exclusion takes. Some forms of discriminations are manifest and deliberate, unofficial, or subtle and unintended. It is the vicious cycle of social exclusion that causes the poverty of particular people, leading to higher rates of poverty among affected groups. The productive capacity and poverty reduction rate is reduced by social exclusion. The development of a society as a whole is obstructed and the competent operation of market forces are thwarted which restrains the economic growth.

Socially excluded groups often do participate but on unequal terms. Labour markets illustrate this most clearly by exploiting the powerlessness of excluded groups and at the same time reinforcing their disadvantaged position. It is the logic of social exclusion that enlighten why some groups of people of society remain backward and poorer than others, have less food, die younger, are less economically or politically involved, less educated and are less likely to benefit from services. It is the social exclusion that leads to conflict and insecurity. Excluded groups who are the victim endure from multiple disadvantages that may come together when they have multiple sufferings, unequal rights, denied rights, discriminated and feel marginalized from the mainstream society. Social excluded people are easy victims of discriminations and stereotypical behaviors. One can see social exclusion among non-disabled groups 


\section{Crossing the Border: International Journal of Interdisciplinary Studies}

as socially generated barriers that reduce the ability of the excluded to interact with society. Room (1995) adds a new dimension to the discussion on social exclusion by couching the issue of social exclusion in a rights-based language when he talks about social exclusion as the denial or non-realization of civil, political, and social rights of citizenship.

Stereotypes are frequently cultured through socialization and armored through social interactions between members of different groups. Stereotypes may be discerned like usually derogatory epithet for ethnic groups, announcement concerning perceived appearance which may contain typically depressing emotive meaning, endow with a linguistic gauge of past and present relationships between the objectgroup and the name-callers. The realities of stereotypes embedded with social constructs about ethnicity cannot be ignored, which is lucid from the noteworthy gap between the share of population of ethnic and Dalit in relation to their school going age population and enrollment in Nepal. This explains why a significant number of children of ethnic and Dalit children are outside the educational system. Among multiple reasons, poverty and social discriminations embedded with stereotypes are the major ones.

The Dalit, ethnic and marginalized groups' leaders not only want a change of the political system but also socio-political modifications and economic participation at a broader range. However, it was only after the political change of 1990 that ushered in an exclusively new situation, and fired the starting gun, so to say, on a rapid and not entirely predictable process of ethnogenesis similar to what happened in India under the British Raj and for rather similar reasons (Whelpton, 2005). The surprising rise of identity politics after the restoration of democracy in 1990 led to increasing academic and political attention on political exclusion and ethnic politics, however, many aspects of exclusion yet to be analyzed, additional dimensions of exclusion and inequality requiring further calisthenics. The interactions between formal and informal institutions and political exclusion, inter-group inequality, ethnicisation of the business sector and the country's protracted democratization entail further glance.

Ethnicity does not always emerge from historic tradition or nationality, but is formed, socially/culturally constructed, adapted, recreated, or even manufactured or even misused in the modern society. In post $1990 \mathrm{Nepal}$, ethnic differences began to acquire increasing political salience. The census data revealed the population size of different ethnic groups and liberal political environment encouraged the different groups to organize openly for the first time. For the first time, Nepalese and their friends have had to learn a new word for 'tribe' since the beginning of the 1990s, namely, janajati (a word fairly synonym to ethnic group). The term seems to have come into Nepali from Bengali, via Darjeeling (Gellner, 2007). He argues that it was completely unknown in the early 1980s, started to be used in activist circles shortly before 1990, and now has wide currency among the political elite, though it is still far from being universally recognized in the wider population. Since 1990, there has been a dramatic shift in the orientation toward ethnicity in terms of approaches used in different studies. Though, studies on prejudice are very few done in the context of Nepal, the history is evident of its metamorphosis in terms of approach and actual practices. Both conscious and obvious factors are responsible in such a transformation on the pattern of ethnicity and prejudice in Nepal. Locating the existing cul- 


\section{REFORMS AND CHANGES IN NEPAL . . .}

tural and ethnic groups is still under process even at the present when the country is struggling hard to find a new constitution that can introduce and incorporate the rights and sentiments of all ethnic and caste groups.

An ethnic federal state is the major demand of ethnic groups and some political parties and also a major issue on the path of drafting new federal constitution. However, Nepal does not have the historic circumstances on its side as in the United States and Switzerland where already functioning state entities with long history of separate political and administrative existence came forward to form a new federation. State restructuring has created a major challenge in creating federalism in Nepal. Nepal remained a unitary state since the time of unification of Nepal in the late 18th Century. Currently, Nepal being on the path of a federal state means that Nepal will need to revive itself and restructure the state to create federal units so that to delegate more powers to excluded groups. State restructuring often becomes a blazing controversial issue when a country is going federal on the basis of desegregation. But state restructuring on the basis of ethnic federation remains highly disputed and controversial and it continue to plague state restructuring debate and constitution drafting process. The demand of ethnic federation by some political and ethnic organizations has been rejected by major political parties. The Madhesi community's want of entire Terai belt to be declared as Madhes Pradesh has been opposed fervidly. If a federal state in Nepal is organized on ethnic basis, for example, may be Tamuwan or Limbuwan or Magarat or Khasan, the majority of the people in that area are not Tamus or Limbus or Magars or Khasa. Not only do there will be a quandary of minority dominating the majority, but there will be the problem of states which are defined by the ethnic identity of a minority. It will be illogical if we have a glance at the mosaic of different groups in Nepal. To make solely ethnic identity as a basis of political support may be a perilous and misleading philosophy. Hence, organization of the country on the basis of ethnic and religious groups and so on will lead to degeneration and anarchy. The politically premeditated approach drawing on the support of the ethnic, religious groups or caste groups for state restructuring is a flawed ideology that may sow the seeds for future conflicts in Nepal. The people's verdict in 2013 second constitution assembly election mandating those political parties supporting multiple identity federation supports the logic that Nepali masses adhere to a federation with a multiple identity of all ethnic and caste groups. They deem that organization of the country on the basis of ethnic and religious groups may create threat of ethnic sanitization in which a process starts to define people only by their ethnicity or religion whether they are from very wealthy ethnic group or a poor, whether someone is a wealthy Brahmin /Chhetri or poor Hindu.

The context of successful Indian federation is different where the bases of federation are characterized by geographic, regional, cultures and linguistic diversities. The vital feature of federalism is the division of powers between Central and State government and the autonomy enjoyed. The best democratic federalism, one could anticipate in Nepal need to be based on geographic, regional and economic factors with an acceptance of regional, cultural and linguistic differences in different parts of Nepal and proper democratic representation according to population. For this, the reconsideration of the electoral constituencies is indispensable so that to represent the populations in them that would gratify the concerns of the ethnic groups and 


\section{Crossing the Border: International Journal of Interdisciplinary Studies}

their actual population is represented appropriately on the basis of universal rights rather than caste or ethnic identity.

There is no national ethnic policy in Nepal in the present nor there was in the past but the major issues can be whether Nepal can be a haven of all castes and ethnic groups residing in all regions in a real sense and whether the monopoly (in all sectors) of the few elites from dominant caste groups terminates. In this context, social policy should be to accomplish social integration which is a condition of achieving a relatively cohesive and functioning interaction system in a society among different people as a prerequisite to national integration. National integration is a progressive process of identifying commonalities with respect to common goods but it is imperative to uphold and endorse the distinct ethnic identity of each group through social integration within the framework of the current international political boundaries. On national integration Bhattachan and Pyakuryal (1996) fittingly argue that to achieve national integration; all ethnic groups must have shared values in which the cultural aspirations of each groups are also reflected. But, the practice and implementation is difficult and different than discoursing. Achieving shared values and reflections of cultural aspirations of all groups is immensely difficult in a multicultural and multiethnic country. However, it is necessary to be optimistic for the possibilities for a better future as transformations and attitude changes are taking place gradually. The past thinking of regarding ethic issue as communal is becoming flexible and the context for discoursing on ethnic issues and rights of ethnic groups is altering fluidly. However, inclusion of ethnic identity of each group through social integration within the framework of the current international political boundaries requires that ethnic and other marginalized groups need to develop the feeling of leadership, a self-confidence of leading all caste and ethnic groups. Excluded groups need to change stereotype thinking that they are excluded systematically, the entry point is tight, rather need to develop a competitive feeling by enhancing their aptitude in all sectors (including education). The dominant groups also need to change stereotype thinking on ethnic, caste, regional and federalism issues.

One of the major issues raised strongly by indigenous peoples, women, Madhesis, Dalits and other marginalized communities is to increase their participation in the policy making processes and restructure the state of Nepal to make it inclusive, participatory and representative accommodating various communities in the state mechanism. The commitment to State restructuring has been reflected in 12-point understandings signed between seven political parties and the Maoist and 10-point peace accord signed between the government of Nepal and the Maoists. The Interim Constitution of Nepal 2007 has ensured the commitment of the political parties and the government to restructure the State. But the form and character of the state restructure was not clear until indigenous peoples' movement and Madhesi uprising forced the government to declare federal system of administration and amend the Interim Constitution accordingly. Like indigenous peoples and Madhesi communities, women and Dalits could not come to the forefront of the movement on their own due to their political partisan culture and lack of community-based organizations. Yet, with their own distinct and independent demands of property rights and elimination of caste and gender-based discrimination, they supported the on-going movement of 


\section{REFORMS AND CHANGES IN NEPAL . . .}

indigenous peoples and other disadvantaged groups for federalism and proportional representation in the state mechanism.

The collective voice of indigenous peoples, women, Madhesis, Dalits and other disadvantaged communities has partly been heard by the government through separate agreements with these communities and the government has made its political commitment to make federal state inclusive, participatory and representative through proportional representation in all bodies of the government at all level. Major political parties have promised, at least in their election manifestos, for the federal democratic republic government and an inclusive, participatory and representative democracy even though they differ in the contents of federalism. In order to eliminate caste, ethnic, linguistic, religious, gender, and regional discriminations and to address the issues of indigenous peoples, women, Madhesis, Dalits and other disadvantaged groups, the state restructuring has been committed in the Constitution. The basic education in mother language has also been ensured by it. The civil, political and human rights have been guaranteed. The Three-year Interim Development Plan also admits that the centralized and unitary structure of the state is responsible for the social and economic backwardness of indigenous peoples, women, Madhesis, Dalits and other marginalized communities. In order to improve the socio-economic condition of indigenous peoples and other marginalized communities, the Three-year Interim Development Plan has introduced a policy of inclusive development focusing particularly on poverty, health, education, culture, language, natural resources, environment and infrastructure development. It has promised a sectoral approach to address community specific problems. In order to avoid the institutional and legal barriers to the ownership and access of indigenous peoples to natural resources (land, water, forests and mineral resources), it aims to conduct a legal review for introducing the necessary reforms.

In order to ensure the development, protection and promotion of indigenous peoples' culture and languages, a tri-language education policy has been adopted. Despite the equal sex ratio in Nepal, extreme forms of gender based violence (GBV) and discriminations still do exist in Nepal. Life span of women is shorter by two and half years. Maternity mortality rate is the highest in South Asia. They are the victims of gender based violence like Chaupadi tradition (Menstrual taboos restricting women of various rights). Compared to men, they work for long hours (12-16 hours a day). They have a very heavy workload with high level of physical vulnerability. Poverty and illiteracy rate is the highest among indigenous women. Sex abuse, domestic violence and girl trafficking are reported high among them. Women also suffer the most from the political conflict. The Interim Plan has committed to eliminate gender inequality through the legal reforms. Women's empowerment and women development programs have been initiated. Special rehabilitation and reconstruction measures have been committed for conflict-affected and displaced women. Dalits still suffer from the practice of untouchability and poverty. Their indigenous technology and traditional occupations have been displaced by modern technologies and open markets. They need further constitutional reforms to eliminate untouchability and special economic measures including skill development and income generating programs to address their poverty, education and cultural awareness program. The Madhesis have special problem of identity and backwardness. 


\section{Crossing the Border: International Journal of Interdisciplinary Studies}

\section{CONCLUSION}

Democratization of the country and the society is a long, hard slog and it doesn't happen in the same way in different places. Democratization triangle, with three corners - protests, civil society and political parties /opposition facilitate in depicting the connection between political crisis, socio-cultural changes, autonomy and inclusive changes in Nepal. Democracy brings no guarantees. Demonstrations alone do not build democracy but Nepali democracy is experiencing a democratic recession because of unbalanced allocation of rights, powers and resources, corrupt and selfish political practices, semi- feudal practices amidst the rhetoric of Samabesi (inclusion). It will lead to additional crisis and instability, variance and sadism and when politicized acquire a political aroma in the form of social and political unrest. The more imbalanced the regional development efforts and allotment of limited wherewithal and political powers, ethnic, religious and socio-cultural rights; the wider will be the inconsistency of interest between foremost and secondary segments for receiving the power on possessions of rights and political power. The more the public view is unnoticed, fiercer the society will be and if further common masses become aware of their factual combined wellbeing and the selfish corrupt politics of the politicians, the more prone are they to challenge the legitimacy of the existing pattern of selfish, corrupt politics and the status of civil rights. If the emotion of the populace is overlooked there may be more ennui, violence and non-participation of the people in all activities of democratization process.

Terai unrest, rows on the issues of federation and identity politics, struggle for more rights by ethnic minorities, social, cultural, economic and political divergences may create further future problems. The ignorance of regional sentiment may create more tumult in future. Mishra (2007) argues that History of the nation, process, transition etc sought to be intrinsically implicated in all formulations and a present without a past and a future-a historical present are alarming. Hence, the government for getting a way out to diverse predicaments ought to ponder on the historical legacy (past) of exclusivity, inequalities and the perpetuating social-cultural-regional and economic values. The major segments of civil society in Nepal is becoming sentient of peoples collective interests and are perplexed to regional idiosyncrasy, the authority of prevailing pattern of politics and the functioning of political parties. They are demanding for inclusion, the equal distribution of resources and social, economic, regional and political rights and opportunities. The more the activities of dominant ruling political elites and their fraternal organizations try to impose ascendancy, ignore peoples sentiment and make common people and civil society more frustrated by their infuriating activities, the more likely are the civil society, common public to become sentient of their genuine collective interest by corresponding their grievances to each other.

As the socio-political formation of the modern Nepali state is extremely bucolic and power centric hence 'who rules' is a vital apprehension in this country. Social inequalities between rulers and groups (class, ethnicity, gender, etc.) and their role in influencing Nepali politics and society remains imperative. Likewise, the affects of public opinion, civic society, ideologies and social tendencies outside of the formal institutions of political power in affecting formal politics and society in Nepal remains decisive. Political leaders' ideas, policies and activities can have a determinative effect on common people's material, political or social condition. People's 
judgment, views and attitude can also have a decisive effect on - political parties and ruler's status. No sustainable stability, peace, inclusive democracy under a new constitution will be endorsed in Nepal until this interdependent relationship is considered sincerely by people and political leaders. While a loyal opposition based on civil society is clearly a step forward from autocratic rule, further democratic progress may depend on political parties. Democratization needs to overcome their fear of being labeled partisan. Nepalese society is extremely diverse and complex hence steps forward in Nepal is possible only from macro inclusive perspective which could be a yardstick in developing the Nepali society. Not xenophobia but positive protests, civil society, political parties and opposition's factual devotion will provide the common bond of unity in diversity.

\section{REFERENCES}

Bhattachan, K. B, Pyakuryal, K.N. (1996). The issue of national integration in Nepal: An ethno-regional approach. Occasional Paper in Sociology and Anthropology, 5, 67-72.

Bhattachan, K. B. (2009). Discourse on social exclusion and inclusion in Nepal: Old wine in a new bottle. Identity and Society Social Exclusion and Inclusion in Nepal. Kathmandu: Mandala Book Point and Social Inclusion Research Fund (SIRF). $17-21$

Coser, L. A. (1977). Masters of sociological thought. Class Theory. Retrieved 29 Sept, 2009 from<http://www.polycola.com/search.php?stype $\mathrm{s}=$ \&eng 1 =yahoo\&eng $2=$ google $\& \mathrm{st}=\mathrm{Web} \& \mathrm{q}=$ social + class+theory+emerge $\mathrm{d}+$ when $>$

Dahal, D. R. (2000). Nepal's democratic system has failed to cross the barriers of caste, family and kinship. The Telegraph Weekly, 5.

Dahl, R. A. (1971). Polyarchy. New Haven: Yale University Press.

Dahl, R. (1989). Democracy and its critics, New Haven.

Doug McAdam, John D. McCarthy, Mayer N. Zald. (1996). Comparative perspectives on social movements: political opportunities, mobilizing structures, and cultural framings. Cambridge University Press.

Gaize, F. (1975). Regionalism and national unity in Nepal. Berkeley: University of California Press.

Gellner, D. N, J. Pfaff-Czarnecka and J. Whelpton (eds). (1997). Nationalism and ethnicity in a Hindu kingdom: The politics of culture in contemporary Nepal. Amsterdam, Harwood publishers.

Gellner, D. N. (2007). Nepal towards a democratic republic: Caste, ethnicity and equality in Nepal. Economic and Political Weekly of India, 19.5, $18-25$.

Gurr, T. R. (2000). Peoples versus states: Minorities at risk in the new century. Washington, D.C.: United Institute of Peace Press.

Lawoti, Mahendra (2005). Towards a democratic Nepal: Inclusive political institutions for multi cultural society. New Delhi, Sage Publishing.

Lindblom, C. (1959). The science of muddling through. Public Administration Review, 19.

Mishra, C. (2004). Locating the causes of the Maoist struggle. Studies in Nepali 


\section{Crossing the Border: International Journal of Interdisciplinary Studies}

History and Society, 9 (1).

Mishra, C. (2007). Essays on sociology of Nepal. Kathmandu: FinePrint Inc.

Nash, K. (2010). Contemporary political sociology. Oxford: Wiley-Blackwell. Retrieved 21 January 2014.

Room, G. (1995). Beyond the threshold. The Measurement and Analysis of Social Exclusion. Bristol: Polity Press. 43-51

Sassatelli R. (2011). Body politics in E. Amenta, K. Nash and A. Scott (eds). The Wiley-Blackwell Companion to Political Sociology. Oxford: Wiley-Blackwell.

Tarrow, S. (1998). Power in movement. New York: Cambridge University Press.2nd edition.

Truman, D. B. (1951). The governmental process. New York: Alfred A. Knopf.

Whelpton, J. (2005). A history of Nepal. Cambridge: Cambridge University Press.

\section{ABOUT THE AUTHOR}

Dr. Prakash Upadhyay is an Associate Professor of anthropology at Tribhuvan University, Prithvi Narayan Campus, Pokhara, Nepal. He has been teaching to Master level students. He is trained in Denmark and holds a Doctoral degree (PhD) in Anthropology, including a research work equivalent to Post Docs. He has received Master's Degree in five different disciplines - Anthropology, English literature, History, Economics and Political Science. He has published more than 250 research articles and two dozen books nationally and internationally.Email:prak-socio@hotmail.com 